\title{
A Noção de Ser no Mundo em Heidegger e sua Aplicação na Psicopatologia
}

A noção de ser no mundo difundiu-se amplamente pelas ciências humanas desde que foi formulada por Martin Heidegger. Essa noção é aqui revista e caracterizada em seu sentido próprio, de acordo com a obra de Heidegger, e é também analisada sua utilização na psicopatologia existencial de L. Binswanger.

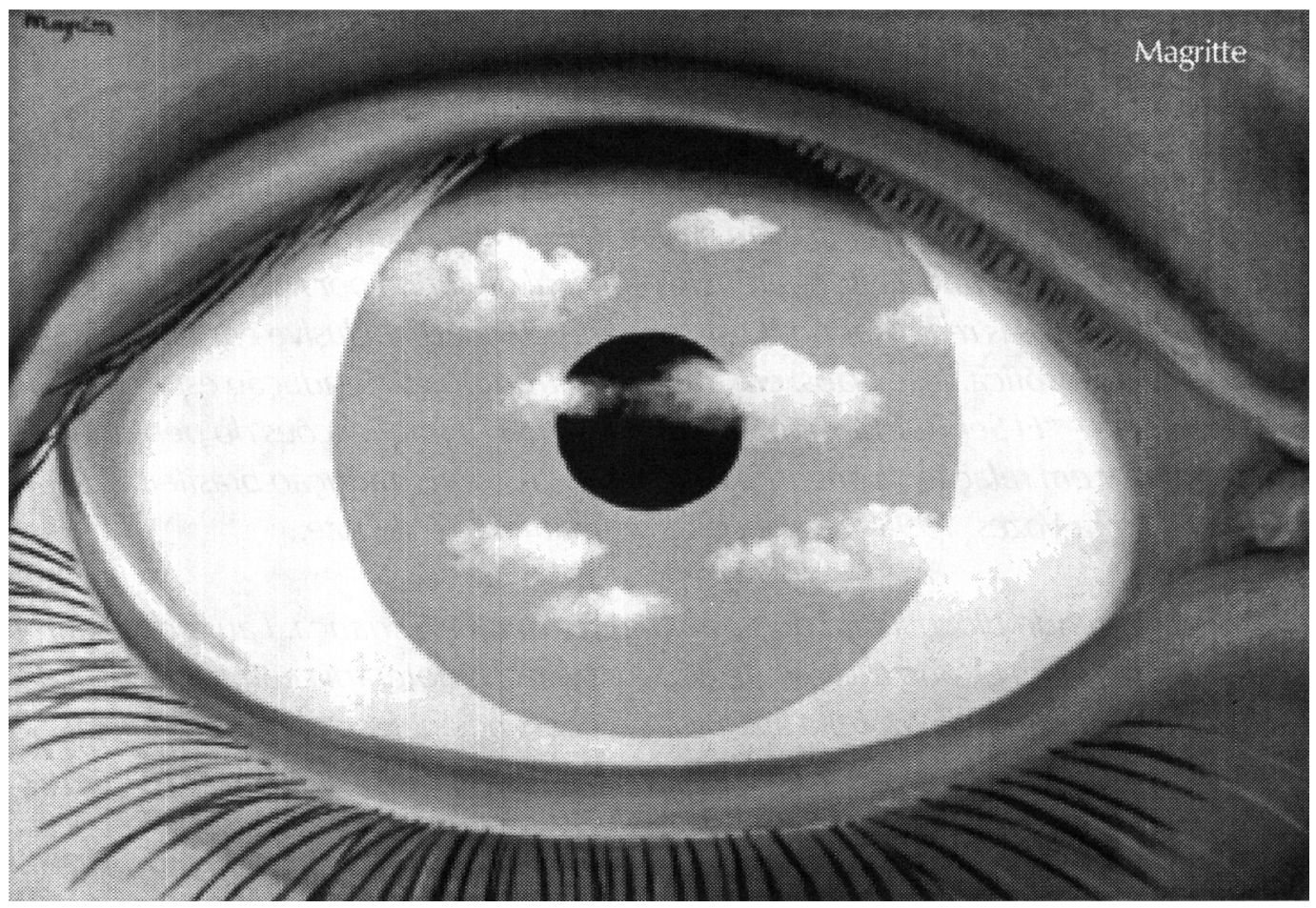

Márcio F. Barbosa

Psicólogo

Aluno do Mestrodo em Sociologia da UFBa.
A expressão serno mundo, que fez e faz escola no conhecimento psicológico e social, é daquelas que facilmente se prestam à banalização e a empobrecimentos, talvez mesmo pela sua abrangência e aparente obviedade. De fato, quem se depara com essa expressão, empregada sem maiores explicações, não suspeita a intricada rede conceitual que motivou a sua formulação. Além disso, não raro a expressão é utilizada como uma espécie de palavra mágica, para além da qual nada é preciso explicar. Por tudo isso, em matéria de psicopatologia, onde a noção de ser no mundo foi largamente empregada, não deixa de ser conveniente que a mesma seja revisitada em seu sentido original.

A noção de ser no mundo foi desenvolvida sistematicamente pelo filósofo alemão Martin Heidegger no tratado Sere Tempo (Sein und Zeit), de 1927. Na obra Heidegger se impõe a tarefa de recolocar a questão do 
"sentido do ser", que para ele foi esquecida pela metafísica tradicional. Esse esquecimento se deu em virtude do fato de a tradição metafísica ter se convertido numa ontologia da substância, aquela que visualiza o ser em geral a partir da primazia da "coisa", ou, dito de outro modo, que toma a "coisa", como paradigma de representação para tudo o que "é". Todavia, essa rejeição da ontologia da coisa que Heidegger julga necessário levar a cabo, não implica para ele em considerar a questão do ser como uma questão abstrata; do ponto de vista existencial, a questão do ser é eminentemente concreta, porque "o ser é sempre o ser de um ente". Resta, contudo, explicitar o que queremos dizer com a palavra ser, compreender o fundamento e a possibilidade do ser de alguma coisa. Por onde se deve, então, começar uma tal investigação? Ora, diz Heidegger, já possuimos, em nossa vida cotidiana, um certo grau de conhecimento do ser, de outro modo a questāo sequer poderia ser colocada. Por isso, para se alcançar uma compreensão do ser é preciso, em primeiro lugar, analisar o ser do ente que coloca a questão do ser, isto é, o ser do homem, o dasein. Assim, toda a primeira seção da obra é devotado à analítica do dasein (daseinsanalyse), isto é, à análise da estrutura do ser no mundo, como horizonte fundamental de onde pode ser abordada a questão do ser em geral.

A reflexão de Heidegger em Ser e Tempo, sua "ontologia fundamental", não apenas se converteu num marco do pensamento filosófico do século $\mathrm{XX}$, mas causou grande repercussão nas ciências humanas. No caso da psiquiatria, a daseinsanalyse foi aplicada, por L. Binswanger e E. Minkowski, entre outros, na compreensão das doenças mentais enquanto modo alterado de ser no mundo. Segundo a afirmação de Binswanger (1977: 46), Ser e Tempo "se tornou indispensável, entre outras coisas, também para a psiquiatria enquanto ciência."

Neste artigo procuraremos, primeiramente, $\mathbf{e}$ nos valendo da recente tradução brasileira de Ser e Tempo (Heidegger, 1995), fazer uma exposição de alguns elementos essenciais da noçāo de ser no mundo tal como delineada por Heidegger. Depois, ilustraremos sua aplicação na psicopatologia, discutindo o seu significado e importância.

\section{O Ser no Mundo em Heidegger}

A investigação fenomenológica de Heidegger é de caráter ontológico, isto é, busca as determinaçōes essenciais do ser dos entes. Dessa maneira, pretende sempre situar-se aquém do plano empírico ou ôntico (dos entes) e constituir-se na condição de possibilidade do mesmo. Assim, as estruturas ontológicas explicitadas na análise do dasein (como ocupação, disposição, compreensão, discurso) não devem ser confundidas com aqueles que seriam os seus correlatos ônticos ou empíricos (afeto, desejo, conhecimento, linguagem) na verdade, tais estruturas são a fundamentação existencial dos mesmos. A analítica existencial "está antes de toda psicologia, antropologia e, sobretudo, biologia." (Heidegger, 1995: 81) ${ }^{1}$. Ela corresponde à abertura de um a priori mas sem que isso signifique uma "construção apriorística" (ibid: 87), isto é, desvinculada de toda "empiria". Com efeito, a pesquisa científica e a pesquisa ontológica podem até convergir, esta última tendendo sempre para uma maior "purificação" e transparência do que se descobriu onticamente. A investigação científica realiza uma primeira e tosca "fixação dos setores dos objetos", e só o faz a partir da abertura originária ao modo de ser dos entes pela qual a experiência ordinária do mundo é responsável. Para que o questionamento científico possa abordar uma determinada região dos entes, é preciso antes que essa região seja elevada do horizonte da experiência original - o horizonte da relação fundamental do ente que questiona com o mundo questionado.

Por isso o ser do homem, a pre-sença ${ }^{2}$, possui uma dimensão ontológica fundamental. $\mathrm{Na}$ verdade, no texto de Heidegger, o status da pre-sença é ambíguo. De um lado, ela é um ente, o ente que cabe à analítica existencial
1-Paul Ricoeur (1994: 97), contudo, reconhece uma dimensão antropológica das categorias ontológico-existenciais de Ser e Tempo. Segundo afirma, a análise de Heidegger precisa "ter uma certa consistência no plano de uma antropologia filosófica para exercer a funçáo de abertura ontologica que the assinalada."

2- O termo "dasein", comumente vertido para o português como "ser-al", foi traduzido por Márcia de Sá Cavalcante pela expressão "pre-sença". Cf. a justificação na nota explicativa n. 1, p. 309 da edição referida. 
investigar e que é o equivalente de homem. Por outro lado, a pre-sença não deve ser entendida como sinônimo de "homem", pois ela é uma determinação ontológica, já que corresponde ao ser desse ente que coloca a questão do ser. A resposta a esse dilema encontra-se no fato de que Heidegger considera que a pre-sença é um ente especial, um ente que é, em si mesmo, ontológico, na medida em que é o único ente de cujo ser faz parte uma abertura originária ao modo de ser de todos os outros entes - isto é, é constitutivo do ser do homem o desvelamento do sentido do "é", a partir do qual o mundo

\section{a pre-sençanão deve ser entendida como sinônimo de "homem", pois ela é uma determinação ontológica, já que corresponde ao ser desse ente que coloca a questão do ser.}

3- Isso não significa, de modo algum, que a pre-sença está isenta de qualquer determinação espacial. A questão do espaço e da espacialidade de pre-sença $e^{\prime}$ discutida por Heidegger no terceiro capítulo ("A mundanidade do mundo\%, seção $C$. Sobreo assunto, cf. Villela-Petit (1996).

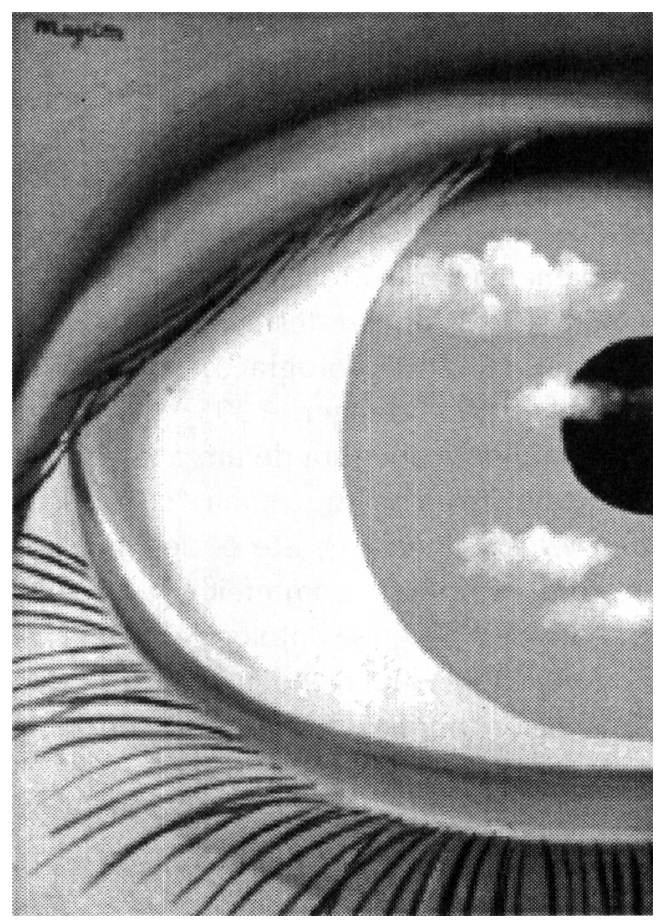

nos advém como sendo de determinada maneira. Essa característica da pre-sença se tornará mais clara com a explicitação da estrutura do ser no mundo - o ser no mundo, aliás, é justamente a constituição ontológica da pre-sença.

O ser no mundo pode ser visivelmente desmembrado em três partes, que são seus momentos constitutivos: o "ser", o "mundo" e o "em". Dito de outro modo e em outra ordem: o mundo em que o ser é, o quem que é no mundo, e o modo de ser-em em si mesmo. A cada um desses momentos é dedicado um capítulo da obra (capítulos terceiro, quarto e quinto, respectivamente). No entänto, o ser no mundo é uma estrutura unitária, e só pode ser decomposta para efeito de análise. A própria análise, na verdade, demonstra essa unidade, pois o "mundanidade" só se deixa caracterizar mediante uma compreensão do ser para quem existe um mundo, o ser que é-no-mundo, por sua vez, só se revela a partir de sua "morada" (o mundo), e a relação de ser-em pressupõe a compreensão dos termos que se relacionam no modo do "em". Em suma - e isso é fundamental para se compreender a idéia de ser no mundo em toda sua profundidade -, a explicitação da estrutura da pre-sença já traz consigo o desvelamento do mundo e viceversa.

Pode-se dizer que a aparente obviedade do ser no mundo deriva da naturalidade com que esse "no" se nos aparece. Grande parte da importância do pensamento de Heidegger consiste em ter ele problematizado o "ser-em" da existência humana. Para uma coisa, um objeto (que a terminologia heideggeriana designa por "ser simplesmente dado"), o "em" corresponde ao "dentro", a uma relação meramente espacial de inclusão. Mas de que modo se pode dizer que o homem (um ente dotado do modo de ser da pre-sença) está "em" o mundo? Não é suficiente dizer que a pre-sença está "dentro" do mundo, que está simplesmente "aí", que o homem foi uma vez abandonado ao mundo. $\mathrm{O}$ "dentro" não pode se adequar a um ente que, em certo sentido, traz o mundo "dentro" de si ${ }^{3}$. O homem não "é", primeiramente, para depois criar relaçōes com um mundo, ele é homem na exata medida de seu ser-em, isto é, na exata medida em que possui um mundo ou abre o sentido de um mundo. Não existe anterioridade entre esses dois movimentos. "Assumir relações com o mundo só é possível porque a pre-sença, sendo-no-mundo, é como é." (Heidegger, 1985: 96) Por isso, para Heidegger, dizer que o homem "tem um mundo" nada significa, do ponto de vista ontológico, enquanto não se esclarecer o caráter desse "ter". 
Os vários modos de ser-em da existência humana caracterizam, dessa maneira, a essência do homem, isto é, o fato de ele existir, em sentido próprio. Vejamos quais são esses modos.

Nossa relação primeira com o mundo não se dá por nenhuma forma de conhecimento. Dáse através do manuseio, do uso, do contato com os entes "que vêm ao encontro dentro do mundo", com instrumentos, e esse modo de ser-em é denominado ocupação (Besorgen). O que Heidegger chama de instrumento não são apenas os objetos que utilizamos para fazer alguma coisa, mas tudo com que nos deparamos em nosso mundo e assume um sentido dentro dele (a lua é também um instrumento para nós). $\mathrm{Na}$ verdade, falar em "coisa" aqui não seria adequado ontologicamente, porque a coisa já é derivada de uma atitude de conhecimento da pre-sença, onde "já se recorre implicitamente a uma caracterização ontológica prévia." (ibid: 109) No conhecimento, algo é posto como tema, e a "coisa" é uma entidade tematizada. Já os instrumentos são para nós antes de qualquer visão temática, antes de refletirmos sobre eles, antes de os objetivarmos. A ocupação é, portanto, atemática. Não precisamos "ter consciência" de alguma coisa para dela nos ocuparmos; antes, só podemos ter consciência de alguma coisa a partir de um universo de ocupaçōes. Heidegger exemplifica a multiplicidade dos modos de ocupação: "ter o que fazer com alguma coisa, produzir alguma coisa, tratar e cuidar de alguma coisa, aplicar alguma coisa, fazer desaparecer ou deixar perder-se alguma coisa, empreender, impor, pesquisar, interrogar, considerar, discutir, determinar..." (ibid: 95) Pertencem igualmente à ocupação "os modos deficientes de omitir, descuidar, renunciar, descansar, todos os modos de 'ainda apenas' no tocante às possibilidades da ocupação." $E$, podemos acrescentar, também a desocupação e o "não fazer nada" são maneiras, existencialmente falando, de ocupar-se.

Mas os instrumentos, as "coisas" de nossa ocupação, nunca "são" isolados, eles integram um todo instrumental (que em última análise é o próprio mundo). Os instrumentos referem-se sempre a outros instrumentos, e o conjunto de todas essas referências é que constitui o meio original do nosso ser no mundo. O que primeiro vem ao encontro no mundo não são os objetos de um quarto, mas o quarto, $\mathrm{e}$ não como espaço geométrico, mas como lugar de morada - só a partir deste último é que pode existir o quarto enquanto espaço vazio. E o quarto se encontra numa casa, que se encontra numa cidade, e esta se opōe ao "campo". A partir da multiplicidade de referências do todo instrumental cada instrumento se situa. Assim, dizemos coisas

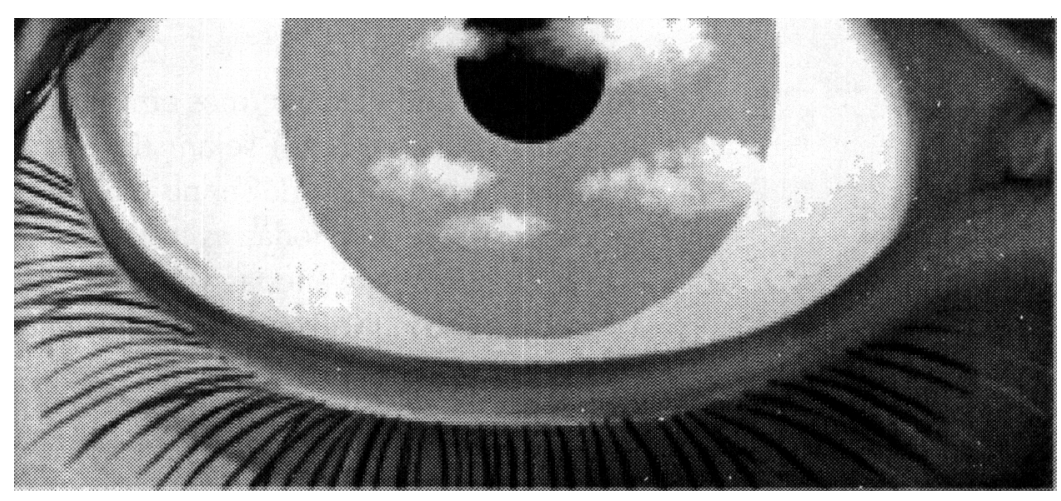

muito diferentes com "o meu quarto" e "um quarto de hotel", embora ambos sejam quartos, porque a primeira expressão está referida à minha intimidade e ao meu "lugar" mais familiar, enquanto a segunda evoca a impessoalidade de um lugar onde se encontra alguém que, ao menos momentaneamente, está sem "lar". Mesmo a natureza, antes de ser a natureza "em si", que a posteriori o homem tematiza como tudo que não é humano, é a princípio integrante do todo instrumental (a iluminação das ruas traz uma referência implícita ao instrumento "escuridão").

Assim, a pre-sença se "absorve", de modo não temático, no todo instrumental. Esta inserção é, existencialmente, a forma mais profunda de conhecimento (lembremos a etimologia latina da palavra "conhecimento": co-nascimento, nascer junto com). Quanto
... porque a coisa já é derivada de uma atitude de conhecimento da pre-sença, onde "já se recorre implicitamente a uma caracterização ontológica prévia." (ibid: 109) 
menos se olha "de fora" um instrumento mais se sabe manuseá-lo, e é o uso que primeiramente desvela o instrumento: "O próprio martelar é que descobre o 'manuseio' específico do martelo." (ibid: 111) Não se deve pensar, contudo, que o modo de lidar com os instrumentos, por ser atemático, seja "cego". "Possui seu modo próprio de ver que dirige o manuseio e lhe confere uma segurança específica" (ibid: 11) - por exemplo, a segurança característica de quem domina uma "arte", seja o músico ou o marceneiro. A ocupação se "subordina" à multiplicidade de referências do todo instrumental, e seu modo próprio de ver é "a visão desse subordinarse", denominada por Heidegger "circunvisão". E o que a circunvisão "vê", de modo originário e necessário, é o seu mundo circundande (Umwelt). ${ }^{4}$

Como se vê, embora os termos empregados (ocupação, instrumento) sejam típicos do "homo faber", o modo de ser no mundo da ocupação refere-se a todas as instâncias da existência humana, e a todas as "coisas" que a pre-sença encontra no mundo. Assim, apesar de Heidegger não fazer nenhuma referência

4 = Inten ante notarque Umwelté tambem o termo alemio correspondente ao conceito de "meio decomportamento", formulado por Komka nos seus Principios de Parcalogia da Gestalt (cf. Lyotard. 1986, p. 58)

5. Como se sabe, coube a MerleauFony, ha sua Fenomenologia da pencepto, de 1945, exploraçăo exaustiva e sistemática da corporeidade do ser no mundo (Merleau-Pono, 1996).

6. Heideger, no entanto, apenas pressupds o ser-com, quando na verdade é preciso explicitar como ele se di (4votand, 1986, p. 80). Mais uma ver, coube sobretudo Merteau-Pono (1980; 1996) essa tarefa, fundando a coexisténcia originatia nto numa relagado entre consciencias, mas numa relaçáo entre meu corpo e o corpo do outro.

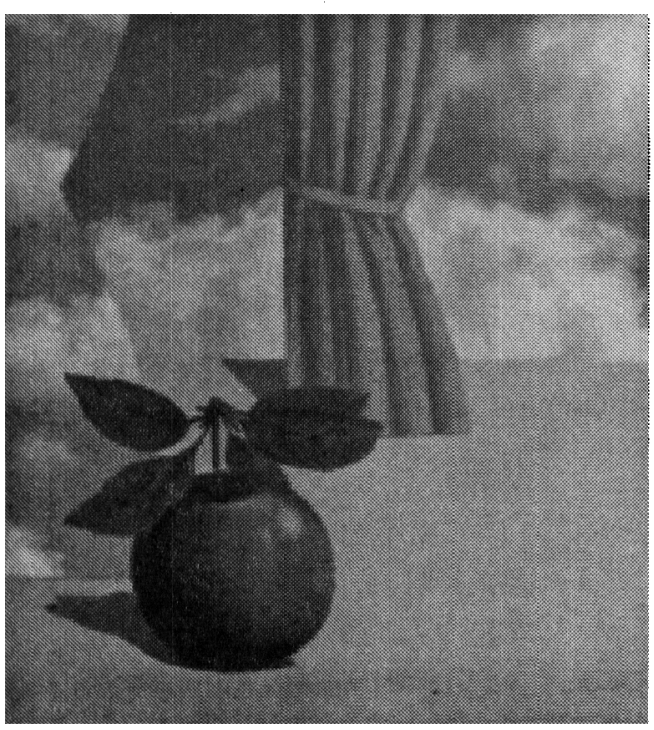

significativa à nossa existência corporal, a circunvisão que o corpo próprio dirige ao seu todo instrumental (espacial) está logicamente implicado na análise acima ${ }^{5}$. E é certo que o homem também se "ocupa" com outros homens, mas este ocupar-se possui um status especial em virtude de ser um modo de relação em que a pre-sença se relaciona com outros entes dotados do modo de ser da pre-sença. O homem "carrega" sempre consigo uma referência a outros homens, $o$ "ser-com" (Mitsein) é um modo de ser básico do ser da pre-sença ${ }^{6}$. De um modo geral, o ser-em da ocupação caracteriza uma relação homem-mundo que não é simplesmente a de dois seres exteriores um ao outro, mas a de um entrelaçamento ontológico dotado de sentido. Entretanto, o modo da ocupação ainda não é suficiente para caracterizar plenamente o ser no mundo. Outros modos de ser-em apreendem melhor, ontologicamente, a região do ser tematizada empiricamente como "psique" - mas que, por ser uma apreensão ontológica, e no modo do ser no mundo, corrige o caráter substancialista que costuma acompanhar a tematização do "psiquismo". Afinal de contas, a pre-sença não é uma substância, mas um exercício de existir. Vejamos então a disposição e a compreensão.

$\mathrm{O}$ "pre" da pre-sença representa sua abertura ao mundo. Mas o ser da pre-sença é justamente sua abertura: "A presença é a sua abertura. "Mas de que modo a pre-sença "se abre" ao mundo? Em primeiro lugar, a partir da "disposição". "O que indicamos ontologicamente com o termo disposição é, onticamente, o mais conhecido e o mais cotidiano, a saber, o humor, o estado de humor." (ibid: 188) Qualquer forma de humor, a simples passagem de um estado de humor para outro, a apatia no humor, todos esses fenômenos que muitas vezes são tidos pela própria pre-sença como insignificantes não são "um nada". Atestam a contínua existência do humor. A disposição é o modo de ser-em com que nos sentimos, nos encontramos, enfim, com que nos dispomos no mundo. Mas não se deve confundir a abertura do ser no mundo no humor "com o que a pre-sença 'simultaneamente' ai conhece, sabe e acredita." (ibid: 190) A abertura da disposição é o solo originário de onde emerge e se desenvolve o que é representado pela pre- 
sença como emoção e afeto. E essa gênese, evidentemente, não é necessariamente acompanhada (nem mesmo na maior parte das vezes) por um movimento de "consciência". Diz Heidegger: "Também a falta de humor contínua, regular e insípida, que não deve ser confundida com o mau humor, não é um nada, pois, nela, a própria pre-sença se torna enfadonha para si mesma. Nesse mau humor, o ser do pre mostra-se como peso. Por que, não se sabe. E a pre-sença não pode saber, visto que as possibilidades de abertura do conhecimento são restritas se comparadas com a abertura originária dos humores em que a pre-sença se depara com seu ser enquanto pre." (ibid: 188) Aqui se mostra, acreditamos, a direção que deve seguir uma explicitação ontológicoexistencial do que é tematizado (talvez na via inversa da gênese do ser) como "inconsciente". Porque a própria abertura com que a pre-sença se depara se the aparece como "enigma inexorável", e qualquer "vivência" que uma "reflexão imanente" possa apreender só se torna possível porque o pre já se abriu originariamente. "O 'mero-humor' abre o pre de modo mais originário, embora também o feche de modo ainda mais obstinado do que qualquer não percepção." (ibid: 191)

Significa tudo isso que a pre-sença jamais se compreende em sua abertura? De modo algum. Para Heidegger, a "compreensão" é um modo de ser-em tão originário quanto a disposição. Mas aqui não se trata da compreensão entendida como forma de conhecimento; esta última, na verdade, só é possível a partir da compreensão em sentido existencial. O ser no mundo mantém-se na familiaridade da convivência ocupacional, situado num conjunto de remissões referenciais que constituem um todo significativo. "Na familiaridade com essas remissões, a pre-sença 'significa' para si mesma, ela oferece o seu ser e seu poderser para uma compreensão originária, no tocante ao ser no mundo." (ibid: 132) Ao compreender o "em função de" da referência ocupacional, a pre-sença abre uma "significância" que diz respeito a todo ser no mundo e a ela própria. Além disso, a presença, por existir no modo de uma abertura, é o único ente de cujo ser faz parte o que ela ainda não é, de cujo ser atual faz parte suas possibilidades, a pre-sença sempre é o que ela pode ser. Pelo fato de "ver" possibilidades em função das quais ela é, a pre-sença se

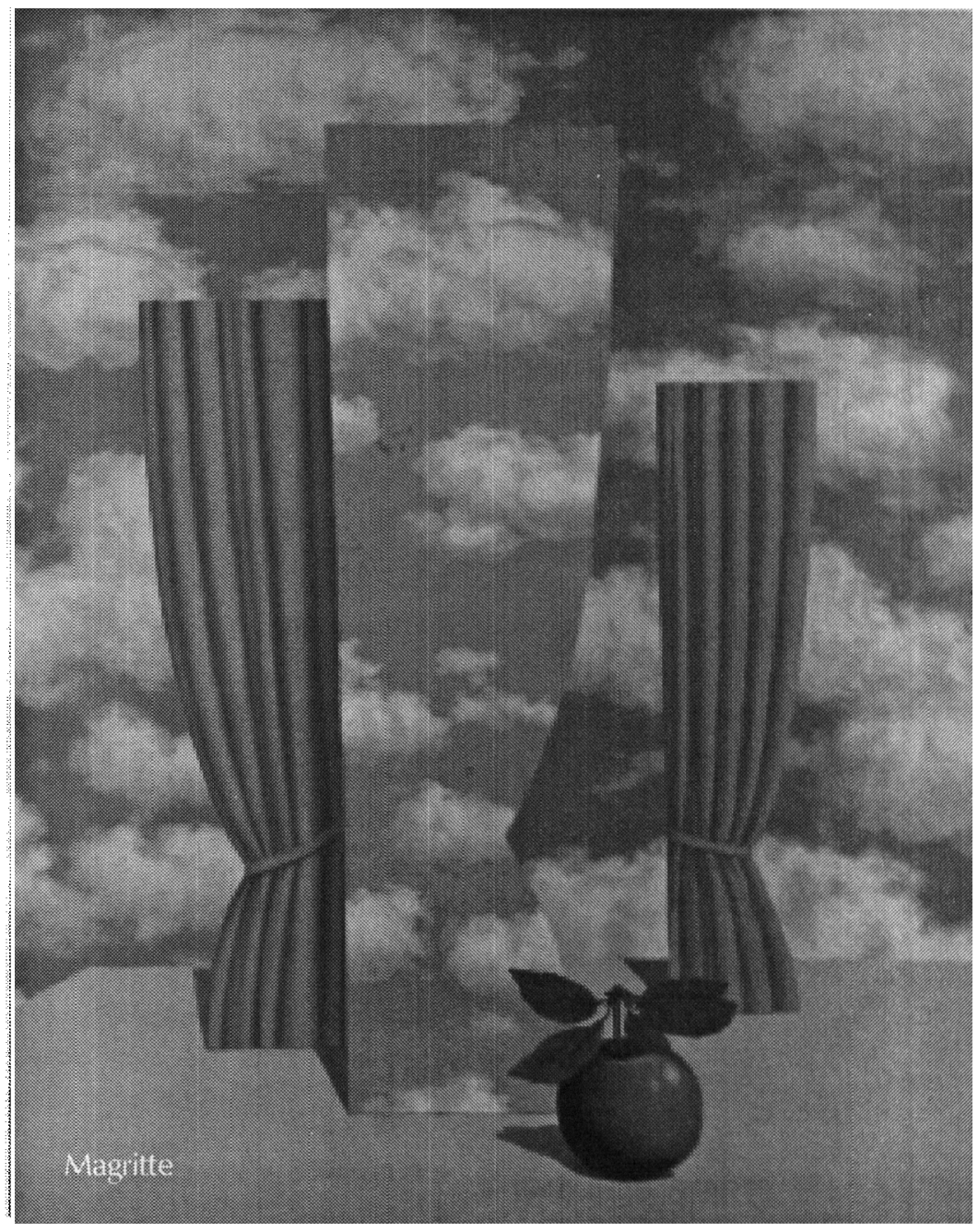

"compreende". "Compreender é o ser desse poder-ser. (....) A pre-sença é de tal maneira que ela sempre compreendeu ou não compreendeu ser dessa ou daquela maneira. Como uma tal compreensão, ela "sabe" a quantas ela mesma anda, isto é, a quantas anda o seu poder-ser." (ibid: 199-20) Não é demais enfatizarmos: esse saber "a quantas ela mesma anda" não denota um processo de consciência, pre-sença não é consciência.
"Opróprio martelar é que descobre o 'manuseio' especifico do martelo." (Ibid: 111) 
Esse "saber" se presta muito bem, por exemplo, ao entendimento da situação comumente conhecida em que o indivíduo ignora conscientemente o que se passa consigo, mas o seu comportamento, visto como um todo, possui sentido, coerência e aparenta já saber desde sempre "aonde queria chegar". Com o tema da compreensão Heidegger não pretende contradizer o desconhecimento essencial da disposição. Compreensão e "saber", aqui, dizem respeito ao fato de a pre-sença constantemente se deparar com sua abertura. "E somente porquea pre-sença é na compreensão de seu

A idéia de ser no
mundo explicito
então o foto de que
o "ser que é" se
constitul enquanto
quem de uma
xistência humana no
mesmo movimento
em que um mundo
se constitui enquanto
mundo, isto é.
enquanto mundo
para esse ser que
nele é.

nele é.

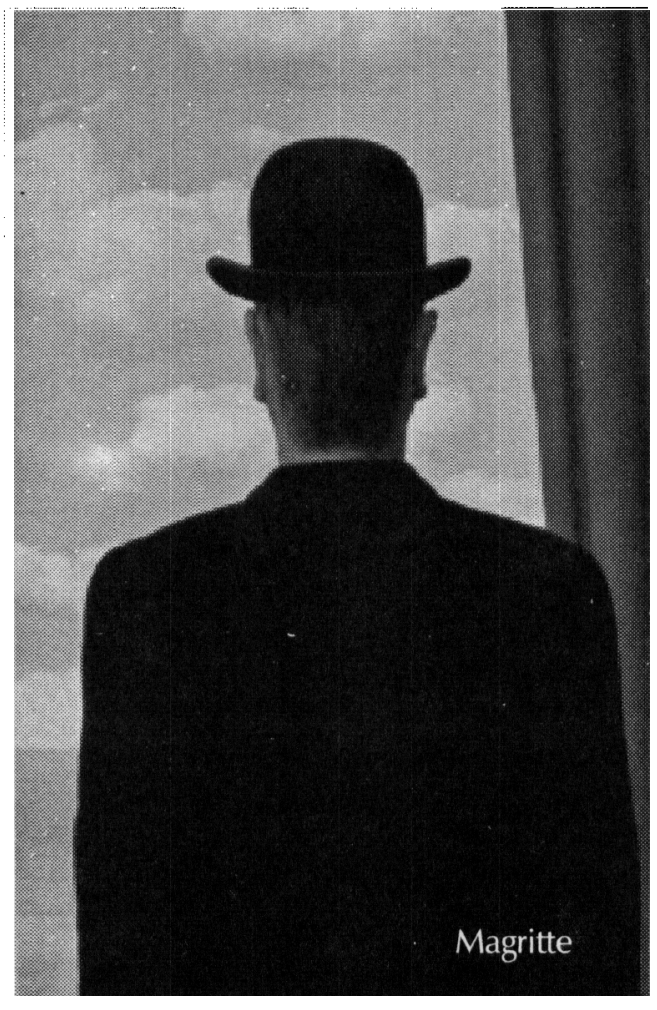

pre é que ela pode-se perder e desconhecer. E na medida em que a compreensão está na disposição e, nessa condição, está lançada existencialmente, a pre-sença já sempre se perdeu e desconheceu. Em seu poder-ser, possibilidade de se reencontrar em suas possibilidades." (ibid: 200)

Desnecessário dizer que a exposição acima é limitada e seletiva. Ela não aborda, nem de longe, todos os temas, desdobramentos e portanto, a pre-sença já se entregou à insights da obra, e mesmo os temas abordados tampouco são analisados exaustivamente. Mas essa breve notícia fornece uma idéia do sentido da noção de ser no mundo na obra de Heidegger, suficiente para que se possa compreender o porquê de sua utilização na psicopatologia.

\section{O Ser no Mundo na Psicopatologia}

A idéia de ser no mundo explicita então o fato de que o "ser que é" se constitui enquanto quem de uma existência humana no mesmo movimento em que um mundo se constitui enquanto mundo, isto é, enquanto mundo para esse ser que nele é. Não há sentimento, comportamento ou qualquer outro modo de ser de uma pessoa que exista isoladamente, como um fenômeno "em si". Essa afirmação, que pode parecer banal, nem sempre é assumida em suas conseqüências últimas. Nenhum desses fenômenos pode, por exemplo, pretender ocupar o lugar de causa primeira, pois a causa primeira é o mundo ou, mais exatamente, o ser no mundo. Se olharmos de perto, veremos que a angústia de uma pessoa, que nos parece "vir de dentro", está também "fora", que em última instância não existe nem "dentro" nem "fora", e que em seu ser alguém só se angustia porque o mundo o arrasta em sua angústia. E por "o mundo" não se quer aludir necessariamente ao mundo enquanto "vastidão", mas à região do mundo abarcada pelo fenômeno em causa - "mundo" significa aqui o polo dessa união indiscernível que o ser-no-mundo busca evidenciar, e que pode ser, a depender da região de "consciência" envolvida, um mundo extremamente "pequeno". A compreensão dessa unidade fundamental do ser no mundo se revela de muita valia para a psicologia, pois a atitude científica muitas vezes se debate para explicar o modo complexo de relacionamento entre certas "coisas" que ela mesma cuidou de separar.

Exemplifiquemos a aplicação do modelo do ser no mundo na psicopatologia através do livro de L. Binswanger, Três Formas da Existência 
Malograda, uma reunião de três ensaios sobre as formas patológicas da "extravagância", da "excentricidade" e do "amaneiramento" (Binswanger, 1977). Partindo da ontologia fundamental de Heidegger, Binswanger procura reconhecer a enfermidade como um estilo ou modo particular de ser no mundo, como variação ou "distorsão" da estrutura ontológica do ser no mundo. Compreender a enfermidade é identificar sua "essência antropológica", isto é, as condiçōes antropológicas de sua possibilidade (pois a modalidade existencial em que consiste a enfermidade, mesmo sendo uma distorsão da estrutura fundamental do ser no mundo, só é possivel a partir desta estrutura, já que é uma variação da mesma). Uma antropologia, com efeito, em sentido amplo, deve evidenciar os modos de ser básicos e as possibilidades concretas e gerais do ser humano. Para alcançar essa evidência antropológica, Binswanger lança mão de um método fenomenológico de reflexão, que busca atingir a essência da enfermidade com base em suas manifestaçōes concretas. Ele examina freqüentemente a significação antropológica de expressōes da fala cotidiana referentes aos fenômenos em causa (que muitas vezes apreendem de modo intuitivo o ser da "doença"), e se vale ocasionalmente de informações sobre o comportamento humano em outras culturas.

A identificação de uma essência antropológica corresponde, do ponto de vista analíticoexistencial, ao delineamento de uma estrutura. Só a partir das condições antropológicas de possibilidade se pode compreender o sentido de uma sintomatologia. Está de antemão fadada ao fracasso qualquer tentativa de derivar a doença a partir da relação entre humores fundamentais e independentes, postulando-se, por exemplo, que um determinado sentimento possa desencadear um determinado comportamento ou sintoma. Mesmo que se identifique esse sentimento como surgido a partir de uma certa situação (situando-o portanto num contexto comportamental), 0 problema residirá em estabelecer essa relação termo a termo entre situação causadora e sintoma. Embora muitas vezes as coisas pareçam se dar dessa forma, pode estar por trás dessa aparência uma estrutura geral da modalidade existencial do indivíduo que, não se dispusesse ela dessa forma, talvez aquela conexão causal não se estabelecesse. $O$ modelo do "distúrbio primário" muitas vezes incorre nesse erro. Se a idéia de "distúrbio primário" tem a vantagem de retirar da base da enfermidade qualquer elemento intencional (no sentido de intenção consciente), ela não é, contudo, o fundamento último, pois não encerra seu sentido em si mesmo, já que só encontra sua razão de ser na estrutura do ser no mundo.

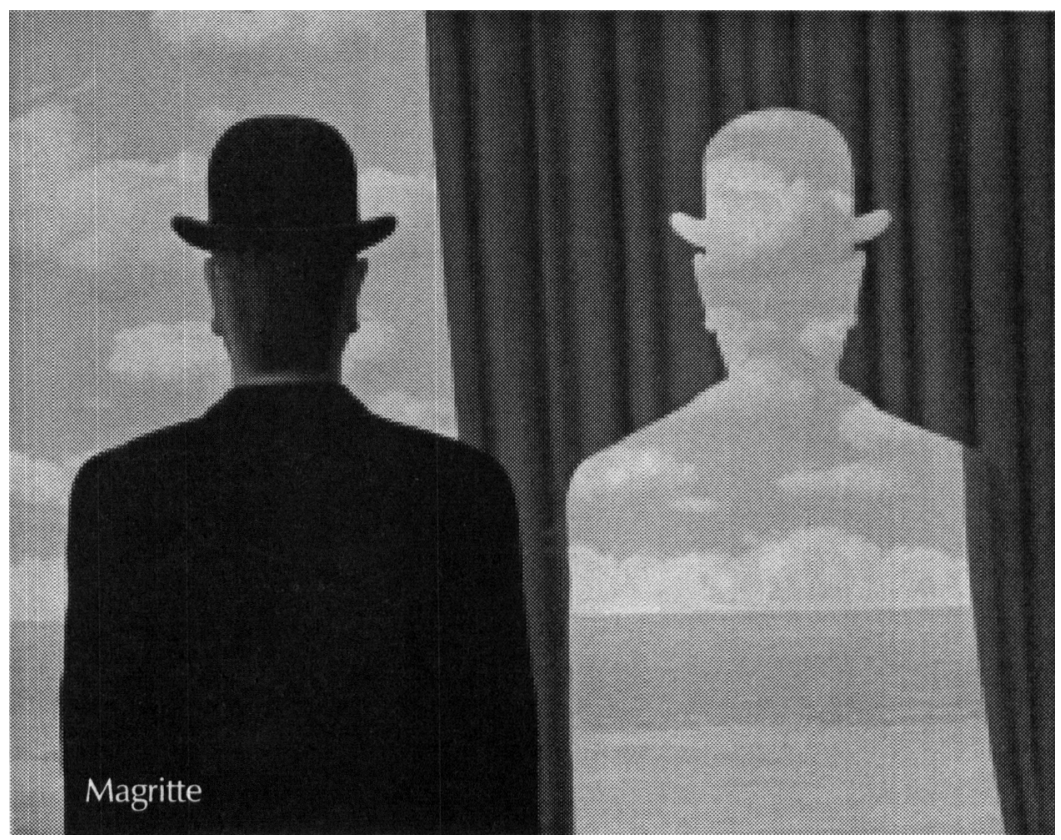

Assim, para Binswanger, a análise existencial se posiciona aquém da distinção intençãodistúrbio primário. Aliás, o ponto de vista existencial também antecede à distinção "com sentido-sem sentido" (Binswanger, 1977: 32-33), porque uma vez que o ser da pre-sença coincide com a unidade fundamental do ser no mundo, não pode haver algo que diga respeito a esse ser e que seja sem sentido.

A perspectiva antropológica compreende um sintoma ou uma síndrome não como uma coisa individual, mas como um estilo de ser no mundo, uma postura total, e que como 
tal pode ser encontrado em vários domínios da atividade humana (para a compreensão do amaneiramento, por exemplo, Binswanger se

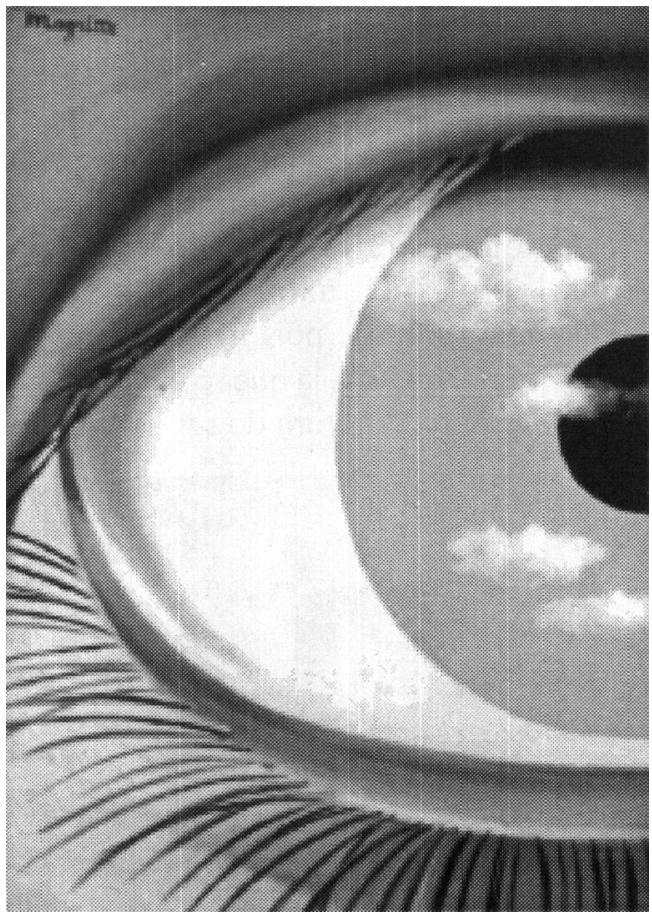

remete ao maneirismo enquanto manifestação artística). O sintoma, enquanto estilo de ser, encontra-se também no normal, ou no doente não apenas enquanto doente, e essa constatação permite compreender melhor o sentido da doença. "Quer se trate de uma 'idéia' extravagante, de um ideal ou 'sentimento' extravagante, de um desejo ou plano extravagante, de uma afirmação, modo de ver ou atitude extravagante, de uma mera 'mania' ou de uma ação ou de um crime extravagante, aquilo que aqui designamos com a expressão 'extravagante' está condicionado pelo fato de o ser-aí ter se atolado numa determinada 'ex-periência'". (ibid: 15) A abordagem existencial, portanto, opera a partir da compreensão do modo como o indivíduo se instalou na estrutura do ser no mundo.

Binswanger, citando Heidegger, define o ser no mundo como um "absorver-se atemático caracterizado pela visão organizadora dos meios - nos remetimentos constitutivos da disponibilidade do todo instrumental" (p. 47) ${ }^{7}$.
O exame clínico, na daseinsanalyse, busca compreender essa "absorção" própria de cada indivíduo. E a enfermidade, como já dissemos, se mostra como uma "distorsāo" da estrutura do ser no mundo - embora seja evidente que o modo de ser "distorcido" também faz parte das possibilidades existenciais da pre-sença. Tomemos, como exemplo dessa distorsão, o caso da extravagância enquanto manifestação patológica (Binswanger, 1977: 14 ss.). Ela se se traduz, existencialmente, por uma desproporção antropológica entre dois modos de ser inerentes ao ser no mundo, a saber, a amplidão e a altura. Assim Binswanger caracteriza esses modos de ser: "A 'atração da amplidão', na direção horizontal da significação, corresponde mais à 'discursividade', ao experimentar, à travessia e tomada de posse do 'mundo', ao 'alargamento do horizonte', ao alargamento do discernimento, da visão de conjunto e da circunvisão organizadora dos meios com relação ao 'burburinho' do 'mundo' exterior e interior. Já a atração da altura, o subir na direção vertical da significação, corresponde mais à aspiração de superar a 'gravidade da terra', de se elevar acima da pressão e da 'angústia das coisas terrenas', mas ao mesmo tempo também à aspiração de conquistar um ponto de vista 'superior', uma 'visão superior das coisas', como diz Ibsen, a partir da qual o homem possa moldar, dominar, numa palavra, apropriar-se de tudo o que 'esperimentou'." (ibid: 17) Amplidão e altura são, portanto, possibilidades próprias da existência humana. O ser no mundo estravagante, contudo, deriva de um descompasso entre o subir da altura e a extensão da amplidão, ele implica que a pre-sença "suba mais alto do que convém à sua amplidão, ao seu horizonte de experiências e compreensão". (ibid: 15)

Nessa elevação precipitada o ser no mundo se perde existencialmente, ele "constrói mais alto do que consegue subir" (ibid: 18). Tratase de uma "preponderância desproporcional da altura da decisão sobre a amplidão da 'experiência'." (ibid: 19) A pre-sença que extravaga desconsidera a "escala da 
problemática humana" e se enrasca num determinado "degrau" dessa escalada, ao qual se lançou em absoluto contraste com "a estreiteza e a imobilidade do horizonte da experiência" (ibid) E do mesmo modo que o alpinista que "se enrasca" numa escalada (por faltar-lhe uma visão de conjunto do despenhadeiro) precisa ser resgatado por outrem, o ser no mundo extravagante (por falta de "discernimento da estrutura da 'hierarquia' das possibilidades da existência humana em geral" - p. 21) precisa ser resgatado desse "entalamento" através da "ajuda" dos outros. "O que chamamos de tarapia", diz Binswanger, "no fundo, consiste tão-somente em levar o doente até um ponto em que ele consiga 'ver' como está constituída a estrutura total da existência humana ou do 'ser no mundo' e em que ponto dela extravagou. Ou seja: resgatá-lo da extravagância, trazendo-o de novo 'à terra', que é o único ponto a partir do qual se pode tentar uma nova partida e uma nova escalada". (ibid: 21)

O essencial a ser observado no exemplo acima é que as imagens metafóricas da "amplidão" e da "altura" buscam dar conta da movimentação própria da existência humana em seu mundo. Como tal, ao menos a princípio, essas imagens são irredutíveis. Elas dificilmente poderiam ser transpostas, por exemplo, seja numa linguagem das "tendências" da natureza humana, seja num modelo de variáveis comportamentais - sob pena de deixaram de expressar aquilo que pretendiam. O tipo de realidade a que essas noçōes pretendem referir é justamente o modo de ser-em da existência humana. Nisto consiste a pesquisa da "modalidade existencial". Enquanto tal, evidentemente, ela se presta não apenas à compreensão de fenômenos patológicos, mas da existência humana em geral.

A perspectiva do ser-em é, acreditamos, o traço essencial da psicopatologia existencial, tal como a encontramos na obra de Binswanger. Mas esse traço distintivo talvez seja ao mesmo tempo o fator responsável por suas dificuldades. Em primeiro lugar, o paradigma da existência não pode ser "operacionalizado" sem descaracterizar-se de modo significativo. A noção de ser-em viabiliza uma visão total da existência, e desse modo essa noção não é passível de ser tematizada como uma realidade circunscrita e objetiva. Nisto consiste, possivelmente, a dificuldade de sua "aplicação". Algumas vezes, por exemplo, as análises de Binswanger parecem esbarrar num meio caminho entre dois extremos, a saber, entre a fecundidade da analítica heideggeriana do dasein (que é o seu ponto de partida) e a objetividade da psicopatologia enquanto ciência - tornandose, por conseqüência, empobrecedoras em relação à primeira e vagas em relação à segunda.

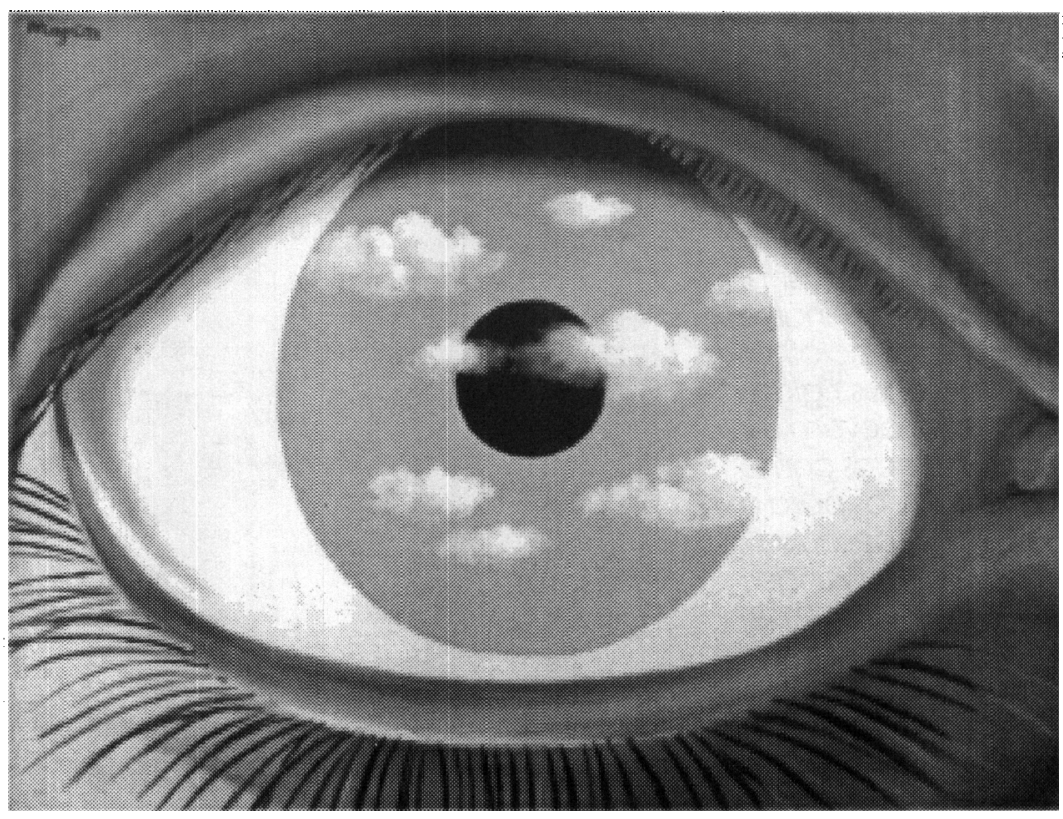

Por outro lado, não se poderia exigir que a daseinsanalyse explicasse por que ocorrem "distorsões" na estrutura "normal" do ser no mundo. Essas distorsōes, de qualquer modo, são possibilidades inerentes ao ser da presença. E mesmo que se identifiquem "causas", sejam orgânicas ou não (e elas podem de fato ser identificadas), e ainda que a abordagem existencial possa tomá-las em consideração, tal identificação não afeta sua visão do 
fenômeno. É nesse sentido que se diz que a noção de existência está aquém do plano dos fatos objetivos observados pela ciência. Esta não é uma limitação do pensamento existencial, é ao contrário o seu valor. A "idéia" básica da fenomenologia não consiste apenas em inserir um mundo de aparências (as coisas tal como elas aparecem) nos meandros de um mundo "real". Essa idéia é

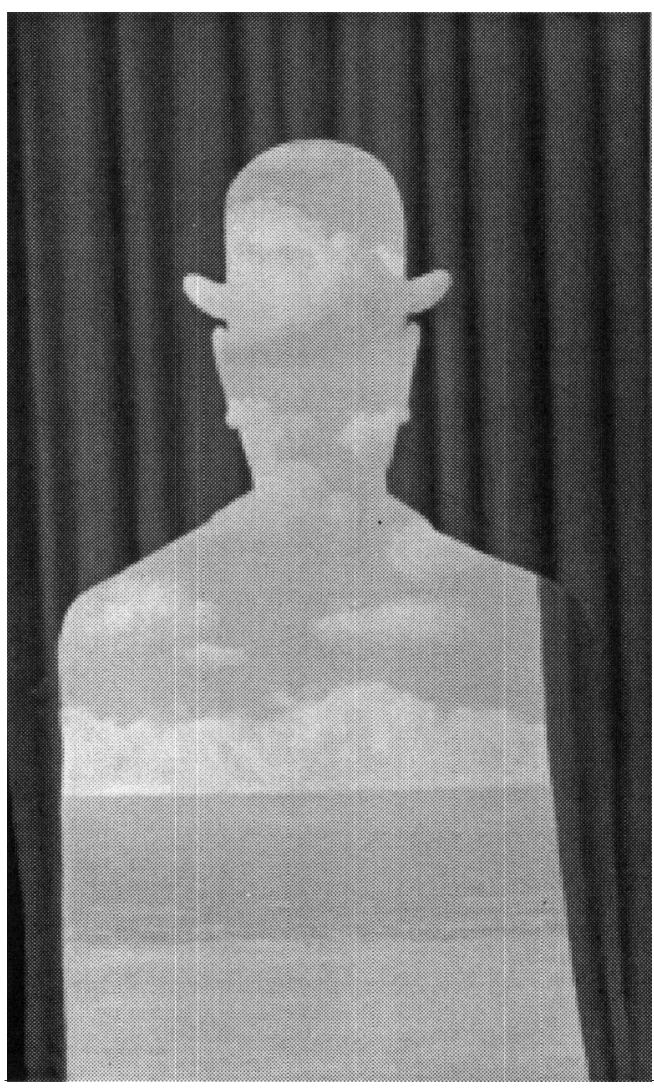

8 - Essa compatibilidade parece ser, aliás, uma aptidão da fenomenologia enquanto método: "Para o filósofo, assim como para o psicólogo, há sempre portanto um problema da gênese, e o único método possivel é acompanhar a explicação causal em seu desenvolvimento cientifico, para precisar seu sentido e colocá-la em seu verdadeiro lugar no conjunto da verdade. É por isso que não se encontrará aqui nenhuma refutaçào, mas um esforço para compreender as dificuldades próprias do pensamento causal." (Merleau-Ponty, 1996:614) muito mais fundamental, e consiste em afirmar que é o nível "do vivido ou do fenomenal que se trata precisamente de justificar e reabilitar como fundamento do nível objetivo." (Merleau-Ponty, 1992: 195-6) De acordo com essa idéia, o campo fenomenal da experiência vivida, da inserção em um mundo, é aquele que dá sentido à existência de certos fatos objetivos isolados. Nessa linha, Binswanger, após identificar a "essência antropólogica" de uma enfermidade, passa a reexaminar os conhecimentos estabelecidos a respeito do comportamento anormal em estudo para, por assim dizer, corrigi-los.
Uma outra dificuldade das análises de Binswanger diz respeito ao método empregado. Ora, vimos, com Heidegger, que o ser no mundo é um a priori existencial (isto é, um a priori que não é "apriorístico" no sentido de ser anterior à experiência). $E$ dissemos acima que a enfermidade pode sempre ser compreendida no plano do ser no mundo, no modo em que ela se dá existencialmente, sem que seja necessário recorrer ao nível das causas objetivas (mas sem que seja proibido fazê-lo). Com efeito, é interessante na perspectiva existencial a visualização do comportamento como atitude geral, como movimentação total da existência em um mundo. Essa visualização de modo algum é incompatível com o estudo objetivo do comportamento e de sua gênese ${ }^{8}$. Mas uma conseqüência desse "recorte" do comportamento talvez seja a linguagem metafórica e imprecisa de que se lança mão para apreendê-lo. Esse tipo de linguagem, contudo, se justifica (embora Binswanger não o afirme expressamente) justamente por visar o ser-em, e porque este não pode ser definido e avaliado "segundo sinais objetivos". Os fenômenos psicopatológicos, enquanto modalidades existenciais, não podem ser apreendidos como realidades substanciais e inconfundíveis. É interessante a posição de Binswanger quanto a esse problema: "Naturalmente, é preciso ter em mente aí que, ao perguntarmos se um determinado fato 'pertence' a uma essência, muitas vezes se trata de uma questão puramente 'de tato', ou seja, de uma questão do domínio da experiência fenomenológica, que não é diferente da questão se determinada obra de arte lingüística pertence à essência artística da poesia lírica, épica ou dramática, não importando a nitidez com que essas essências possam ser contrastadas enquanto tais. (...) Assim como no domínio da arte, também na análise existencial, as definições rígidas devem ser consideradas como obstáculos para a pesquisa". (Binswanger, 1977: 97-8). 
Desse modo, a linguagem metafórica e o caráter abrangente de muitos conceitos utilizados por Binswanger estão em correlação com o tipo de fenômeno visado. A relevância teórica do paradigma da existência na psicopatologia e na psicologia, ao menos em parte, deve ser avaliada de acordo com a importância que possa ter, para a compreensão do comportamento humano, a noção de ser-em, entre outras. A importância da abordagem existencial reside, a nosso ver, no alcance que pode trazer à compreensão da experiência humana, e também no fato de ser um paradigma de investigação científica atento aos fundamentos ontológicos da realidade.

Márcio Ferneira Barbosa

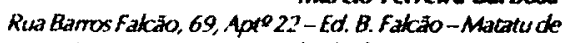

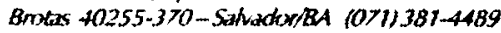

Binswanger, L. (1977) Três formas da existência malograda extravagância, excentricidade, amaneiramento. Rio de Janeiro, Zahar.

Heidegger, M. (1995) Ser e Tempo (parte l). Petrópolis: Vozes.

Lyotard, J-F. (1986) A Fenomenologia. Lisboa: Ediçōes 70.

Merleau-Ponty, M. (1996) Fenomenologia da Percepsaão. São Paulo: Martins Fontes.
(1980) "O Filósofo e sua Sombra" Em Os Pensadores (pp.239-260). São Paulo: Abril Cultural.

(1992) O Visívele o Invisível. Sāo Paulo: Perspectiva.

Ricoeur, P. (1994) Tempo e Narrativa (tomo I). São Paulo: Papirus.

Villela-Petit, M. (1996) "Heidegger's conception of space" Em C. Macann, Critical Heidegger (pp. 134-157). London and New York, Routledge.
Referências bibliográficas 